\title{
Understanding Variability in Adaptive Capacity on Rangelands
}

\author{
Nadine A. Marshall and Alex Smajgl \\ Authors are Senior Scientists, CSIRO Ecosystem Sciences, Townsville, QLD 4811, Australia.
}

\begin{abstract}
The art and science of developing effective policies and practices to enhance sustainability and adapt to new climate conditions on rangelands and savannas are typically founded on addressing the "average" or "typical" resource user. However, this assumption is flawed since it does not appreciate the extent of diversity among resource users; it risks that strategies will be irrelevant for many people and ignored, and that the grazing resource itself will remain unprotected. Understanding social heterogeneity is vital for effective natural resource management. Our aim was to understand the extent to which graziers in the northern Australian rangelands varied in their capacity to adapt to climate variability and recommended practices. Adaptive capacity was assessed according to four dimensions: 1) the perception of risk, 2) skills in planning, learning and reorganising, 3) financial and emotional flexibility, and 4) interest in adapting. We conducted 100 face-to-face interviews with graziers in their homes obtaining a $97 \%$ response rate. Of the 16 possible combinations that the four dimensions represent, we observed that all combinations were present in the Burdekin. Any single initiative to address grazing land management practices in the region is unlikely to address the needs of all graziers. Rather, policies could be tailored to type-specific needs based on adaptive capacity. Efforts to shift graziers from very low, low, or moderate levels of adaptive capacity are urgently needed. We suggest some strategies.
\end{abstract}

Key Words: cattle industry, practice change, social resilience, social typologies, sustainable practices, vulnerability

\section{INTRODUCTION}

Millions of people around the world depend on the grazing resources of rangelands and savannas for their livelihood (Li et al. 2008). However, reports of extensive and severe degradation within these social and agro-ecological systems, resulting from both natural and anthropogenic causes, suggest that their longterm sustainability is uncertain (Stafford Smith et al. 2007; Sietz et al. 2011). The widespread clearing of native vegetation in many regions and its replacement with grazing systems, and the expansion of cropping and ploughing, has additionally and significantly increased erosion and impacted productivity (Hunt et al. 2007; Hobbs et al. 2008).

Degradation processes are especially accelerated during drought periods (Baker 2002; McKeon et al. 2004; Howden et al. 2007). Given that climate models largely predict that by 2030 some areas of northern Australia will be experiencing more droughts and lower summer rainfall (Cobon et al. 2009), effective management of rangelands is becoming urgent (Puigdefabregas and Mendizabal 1998; Briske et al. 2010). Graziers may have to contend with more frequent climate crises (such as drought and flood) and environmental degradation (such as eroding soils and limited production during drought periods) as climate change impacts manifest. If rangelands are to be protected from further degradation, and dependent industries and communities are to be sustained, new strategies to manage them may need to be considered.

Managing rangelands for climate change is about motivating graziers to make appropriate management decisions in the face

Correspondence: Nadine Marshall, CSIRO Ecosystem Sciences, ATSIP Building, James Cook University, Townsville, QLD 4811, Australia. Email: nadine.marshall@csiro.au

Manuscript received 20 September 2011; manuscript accepted 17 June 2012.

(c) 2013 The Society for Range Management of climate variability (Stafford Smith et al. 2009). These decisions need to benefit both graziers and the region. Recognizing critical periods and years (both drought years and years of plenty) can be crucial in determining the extent and magnitude of the impacts associated with climate change (Eakin and Conley 2002; Walker 2005). Knowing when to alter stocking rates, when to supplement feeding, when to agist, when to burn, and when to alter water supplies, for example, can differentiate between those graziers that are likely to be successful at sustaining their land in the long term and those that are not (McAllister et al. 2005; McAllister et al. 2006a; McAllister et al. 2006b; McAllister et al. 2006c). Graziers must also allocate resources each season based on their expectations about prices and rainfall within each season (Anderson 2003; Ash et al. 2007; Marshall et al. 2011). Adaptation success not only depends on keeping productivity at a sufficiently high level during any one season, but also on reducing stocking levels to reduce the impact on the future ability of the land to produce. If stocking rates are too high at the onset of drought, for example, soil sustainability may be diminished and impact on the productivity of future years (Watson 2004; Thomas 2008). While many graziers, however, do employ sustainable practices (Didier and Brunson 2004; Brunson and Huntsinger 2008; Fernandez-Gimenez and Knapp 2009; LaFlamme 2011), not all graziers employ strategies that are likely to be successful over the longer term (Brodie et al. 2001).

To encourage the uptake of sustainable practices and enhance the resilience of rangelands, governments and communities have introduced a range of initiatives. These have included regulatory, educational, voluntary, and market-based instruments (Moon and Cocklin 2011). These efforts, however, have been variable in their success (Sankey et al. 2009; Briske et al. 2011; Measham et al. 2011b). This might be because rangelands are biophysically variable, often low and patchy in their productivities and populations, and populations are 
frequently disempowered from policy centers (Cobon et al. 2009; Sietz et al. 2011). This variability might also be attributed to graziers-already dealing with an existing backdrop of conventional drivers, including economic, biophysical, institutional, cultural, and political pressures. Cultural and regulatory changes are likely to be an additional and unwelcome demand (Adger 2000; Berkes and Jolly 2001; Morrison et al. 2004; Marshall 2010). However, we also think that a significant part of the reason that sustainable practices are not adopted by graziers is that policies and practices are typically founded on addressing the "average" or "typical" resource user and do not appreciate the extent of diversity among grazier populations. Implementing resource-protection strategies without sufficient knowledge of the capacity of people to cope and adapt to them may impose levels of stress upon individuals and communities to such an extent that their ability to adapt, tolerate, or prosper under a new system is compromised (Measham et al. 2011a). Such strategies are also likely to result in poor compliance, and the natural resource may remain unprotected (Sutinen and Kuperan 1999).

Understanding social heterogeneity within populations of resource users is important for effective natural resource management and climate adaptation planning (Andersen et al. 2007). We set out to understand the capacity that graziers in the northern Australian rangelands had in adapting to climate variability and adopting new practices, and in particular to examine the variability among them. This study represents an early attempt to directly "match" various potential policy options to the full range of individual "types" on rangelands and savannas. Our aim was to identify the "types" of graziers in rangelands of northern Australia on the basis of their adaptive capacity and discuss whether potential policy options could be devised that are better matched. This knowledge may significantly improve the way in which resource policies are designed and received; social impacts might be minimized and conservation goals might be more easily achieved (Burdge and Robertson 1990).

The capacity to cope and adapt to climate variability has been described in many ways and at various scales and is closely related to the concept of resilience (Nelson and Robinson 2009). Resilience represents a property that sustains social and ecological systems and the capacity of a system to absorb change and reorganize so as to retain essentially the same function, structure, identity, and feedback (Folke et al. 2002; Gunderson and Holling 2002; Colding et al. 2004). Resilience theory predicts that through the maintenance of properties that can confer resilience, resource managers might be able to sustain natural resources and the social systems dependent upon them (Gunderson 1999; Gunderson et al. 2002). We refer readers to earlier work on the resilience and adaptive capacity of resource users in northern Australia and on rangelands to a variety of change events (Walker and Janssen 2002; Marshall and Marshall 2007; Marshall 2010).

Essentially, adaptive capacity is the potential to convert existing resources into useful strategies. At the individual scale, it is not simply having access to resources or diverse options that define capacity, even though these factors might be important influences (Bohensky et al. 2010; Darnhofer et al. 2010; Marshall 2010; Berry et al. 2011). Adaptive capacity has been described elsewhere at the individual scale as comprising four essential dimensions: 1) the capacity to manage risk and uncertainty, 2) the capacity to plan, learn and reorganize, 3) emotional and financial flexibility to incorporate the costs of change, and 4) the level of interest in adapting to change. These dimensions closely resemble factors that confer resilience at other scales (Adger et al. 2002; Gunderson and Holling 2002; Walker et al. 2004). Previous research in social resilience and climate adaptation has used these factors to examine their influence on adaptive capacity in relation to policy perceptions (Marshall 2007) and resource dependency (Marshall et al. 2007). These dimensions describe why some individuals are likely to adapt better than others given the same circumstances and situations (Marshall et al. 2011). In this research context, we applied these four dimensions to assess the capacity of 100 graziers in northern Australia and assessed the extent to which the graziers varied in their capacity to adapt to climate variability and to adopt new practices.

\section{METHODS}

\section{The Case Study Region}

This study focused on the Burdekin River region in Queensland, northern Australia (lat $20^{\circ} 38^{\prime} 37^{\prime \prime} \mathrm{S}$, long $147^{\circ} 08^{\prime} 17^{\prime \prime} \mathrm{E}$ ). The Burdekin "dry tropics" region or catchment is one of the most significant in terms of land management practices in imparting sediment into the whole of the Great Barrier Reef catchment (Brodie et al. 2001). The region is located in northeastern Queensland and covers an area of about 36000 $\mathrm{km}^{2}$. The catchment is bound by mountain ranges on the inland side; draining the western side of the coastal ranges and the eastern side of the Great Dividing Range (Stokes et al. 2006). The area has relatively high temperatures, low humidity, and intensely weathered and leached soils. The climate is characterized by pronounced wet and dry seasons, with most rain falling between November and April. Average rainfall ranges between 650 and $1500 \mathrm{~mm}$ annually (Stokes et al. 2007).

The region is especially dependent on agriculture and mining. Cattle grazing represents about $96 \%$ of land use in the region. The mean size of grazing properties is $280 \mathrm{~km}^{2}$ (Herr et al. 2005). Since the 1970s there has been a general trend to intensify grazing in the region through use of the following: the development of heat and tick resistant strains of cattle, tree clearing and pasture development using exotic pasture grasses and ponded pasture systems, the use of licks and feed supplements, fencing, and rotational grazing systems (Stokes et al. 2007). Most of the agricultural properties are leasehold and family operated. About $55 \%$ of the graziers are under 50 years of age and, about $50 \%$ of graziers are members of Landcare, which is a partnership between communities, government, and business with more than 4000 volunteer community groups across Australia (http://www. landcareonline.com). Production can vary by $30 \%$ between years. For example, profit was negative in two out of five years over the previous 25 years (Griener et al. 2008). Adoption of sustainable grazing practices in the region is attributed to increased levels of formal and informal training and financial capacity, with the driver for adoption being profitability and knowledge (Greiner et al. 2008). Family members have been identified as the most important source of information for 
Table 1. A description of cattle graziers in the Burdekin region, Australia (June 2009).

\begin{tabular}{|c|c|}
\hline & $\%$ agreed \\
\hline $\begin{array}{l}\text { Graziers with family members involved in grazing } \\
\text { enterprise }\end{array}$ & 94.8 \\
\hline Self-employed & 92.7 \\
\hline My property is crown leasehold & 75.8 \\
\hline My property is both leasehold and freehold & 10.0 \\
\hline Proportion of income from the cattle enterprise & 53.4 \\
\hline Most $(76-100 \%)$ income derived from cattle enterprise & 79.5 \\
\hline Property income between $\$ 150,000-500,000$ per annum & 36.7 \\
\hline Property income greater than $\$ 5$ million & 3.8 \\
\hline $\begin{array}{l}\text { After-tax income }{ }^{1} \text { between } \$ 30,000 \text { and } \$ 60,000 \text { per } \\
\text { annum }\end{array}$ & 30.8 \\
\hline My business is about breeding cattle & 23.3 \\
\hline My business is about breeding and growing cattle & 66.3 \\
\hline Mean number of employees & $2.7(\mathrm{SE}=0.1)$ \\
\hline \multicolumn{2}{|l|}{ Local knowledge } \\
\hline $\begin{array}{l}\text { I continually move cattle around depending on } \\
\text { what I think the weather will do }\end{array}$ & 70.8 \\
\hline I have always lived on grazing land & 82.8 \\
\hline Mean years on grazing lands & $24.9(\mathrm{SE}=1.4)$ \\
\hline Mean number of droughts experienced & $7.7(\mathrm{SE}=0.7)$ \\
\hline Mean number of extreme droughts experienced & $3.1(\mathrm{SE}=0.7)$ \\
\hline \multicolumn{2}{|l|}{ Environmental behavior } \\
\hline Mean number of cattle & $3870(\mathrm{SE}=370)$ \\
\hline Mean number of cattle breeds & $1.9(\mathrm{SE}=0.1)$ \\
\hline I have only one breed of cattle & 42.2 \\
\hline I do not produce anything else from my land & 79.8 \\
\hline $\begin{array}{l}\text { I like to think of myself as environmentally } \\
\text { responsible }\end{array}$ & 64.6 \\
\hline
\end{tabular}

${ }^{1}$ The average income of Australian families in 2006 was $\$ 38000$.

decisions on property management including sustainable farming practices (Greiner et al. 2008).

\section{Survey Development and Administration}

Statements for describing adaptive capacity according to the four main dimensions listed above were scoped from the literature, with colleagues and with two graziers, and were then pilot tested (Table 1). Respondents were mostly asked to rate how strongly they agreed with each statement using a fourpoint rating scale $(1=$ strongly disagree, $2=$ disagree, $3=$ agree, $4=$ strongly agree). This scale was especially useful in quantifying and comparing attitudes, since results could be standardized and contrasted (Willock et al. 1999). The decision to use a five-point scale was specifically omitted so as to discourage the use of an "unsure" or "neutral" option, which can be difficult to interpret. Further, respondents are likely to choose "neutral," given the option, yet, if it is not present, they do not seem to request one (personal observation). Respondents were instructed to leave a response blank if they wanted to.

Some statements were worded positively, while others were worded negatively so as to minimize any influence on respondents. Responses to negative statements were reversed prior to analysis. Statements and questions were also asked to understand the population of graziers in terms of their level of dependency on the grazing resource (Marshall et al. 2007; Marshall 2011).

The "face-to-face" quantitative survey was administered to cattle graziers in the Upper Burdekin region, Queensland, between March and July 2007. The research was promoted through the media and graziers were invited via written correspondence to participate in the research. The graziers were contacted by telephone to organize interviews in their homes. A total of 100 graziers participated in the survey, and a response rate of $97 \%$ was obtained (i.e., only 103 graziers were able to be contacted). As there are approximately 120 graziers in the Upper Burdekin region, the sample size represents approximately $83 \%$ of graziers in the region. The correct contact details for the remaining 17 graziers were unobtainable.

\section{Data Analysis}

Adaptive capacity was assessed by the percentage of responses that agreed or strongly agreed to each statement. The means for each dimension of adaptive capacity to climate variability was calculated. Means greater than or equal to 3.0 were considered to represent positive capacity for each dimension, and are represented by a capital letter A, B, C, or D as shown below. Conversely, means less than 3.0 were considered to represent lower capacity for each dimension and are represented by a lower case a, b, c, or d. Each of the 100 individuals was allocated to one of the 16 possible typologies based on the means of each of the four dimensions of adaptive capacity identified by Marshall and Marshall (2007). Using the following letter combinations, individuals were typed according to $\mathrm{A} / \mathrm{a}, \mathrm{B} / \mathrm{b}, \mathrm{C} / \mathrm{c}$, or $\mathrm{D} / \mathrm{d}$, where

$$
\begin{aligned}
A & =\text { high capacity to manage risk } \\
a & =\text { low capacity to manage risk } \\
B & =\text { high capacity to plan, learn and reorganize } \\
b & =\text { low capacity to plan, learn and reorganize } \\
C & =\text { high emotional and financial flexibility } \\
c & =\text { low emotional and financial flexibility } \\
D & =\text { highlevel of interest in adapting to change } \\
\text { d } & =\text { low level of interest in adapting to change. }
\end{aligned}
$$

For example, a grazier with particularly high adaptive capacity on all dimensions would be coded as ABCD, whereas a grazier with low adaptive capacity on all dimensions would be coded as abcd.

\section{RESULTS}

The characteristics of graziers are presented in Table 1 for contextual purposes. A description of the capacity of graziers to adapt to climate variability is presented in Table 2 . Results suggest that for the first dimension of adaptive capacity, graziers perceived the risks associated with climate risks positively. For example, $90 \%$ of graziers thought that they were "more likely to survive drought compared to other cattle producers," and $82 \%$ said that they were "learning to survive drought periods more easily as [they] got older." On the second dimension of adaptive capacity, graziers appeared to plan for 
Table 2. A description of the four dimensions of adaptive capacity for cattle graziers in the Burdekin region, Australia (June 2009).

\begin{tabular}{|c|c|}
\hline Dimensions of adaptive capacity & $\begin{array}{c}\% \text { agreed or } \\
\text { strongly agreed }\end{array}$ \\
\hline \multicolumn{2}{|l|}{ Perception of risk } \\
\hline $\begin{array}{l}\text { I am more likely to survive drought compared to other } \\
\text { cattle producers }\end{array}$ & $90 \%$ \\
\hline $\begin{array}{l}\text { I am learning to survive drought periods more easily } \\
\text { as I get older }\end{array}$ & $82 \%$ \\
\hline $\begin{array}{l}\text { I am prepared to take advantage of a particularly good } \\
\text { season }\end{array}$ & $91 \%$ \\
\hline $\begin{array}{l}\text { I am too young to retire and too old to find work } \\
\text { elsewhere }\end{array}$ & $43 \%$ \\
\hline $\begin{array}{l}\text { I have planned for our financial security in the event of } \\
\text { a drought }\end{array}$ & $81 \%$ \\
\hline $\begin{array}{l}\text { I sell cattle when the prices are high and buy when the } \\
\text { prices are low }\end{array}$ & $39 \%$ \\
\hline $\begin{array}{l}\text { I have many options available to me other than being a } \\
\text { cattle producer }\end{array}$ & $64 \%$ \\
\hline \multicolumn{2}{|l|}{ Planning, learning, and reorganizing } \\
\hline I just hope for the best if there is a drought & $21 \%$ \\
\hline The future will look after itself & $29 \%$ \\
\hline At the onset of drought, I plan a way to survive it & $83 \%$ \\
\hline I deal with the consequences once they occur & $52 \%$ \\
\hline $\begin{array}{l}\text { I am good at doing what I do and trust my own } \\
\text { decisions }\end{array}$ & $90 \%$ \\
\hline $\begin{array}{l}\text { I rely on talking with other graziers to decide what } \\
\text { drought strategy to employ }\end{array}$ & $34 \%$ \\
\hline \multicolumn{2}{|l|}{ Ability to cope with drought } \\
\hline $\begin{array}{l}\text { The uncertainty of the drought is worse than the } \\
\text { drought itself }\end{array}$ & $55 \%$ \\
\hline I know we will survive future drought & $75 \%$ \\
\hline The good years help us to survive the bad years & $83 \%$ \\
\hline $\begin{array}{l}\text { Stress levels greatly increase in my family during } \\
\text { drought periods }\end{array}$ & $83 \%$ \\
\hline $\begin{array}{l}\text { My partner and I have different opinions about how to } \\
\text { manage drought }\end{array}$ & $23 \%$ \\
\hline $\begin{array}{l}\text { Our current level of debt means that drought will be } \\
\text { especially difficult to recover from }\end{array}$ & $29 \%$ \\
\hline Our financial situation is a constant source of worry & $98 \%$ \\
\hline Climate uncertainty is normal part of our everyday life & $91 \%$ \\
\hline $\begin{array}{l}\text { Regardless of what happens, we have made sure that } \\
\text { we are financially secure }\end{array}$ & $79 \%$ \\
\hline $\begin{array}{l}\text { We rely on drought assistance to get us through } \\
\text { drought years }\end{array}$ & $11 \%$ \\
\hline $\begin{array}{l}\text { It is important for me to know how other graziers are } \\
\text { coping in their business }\end{array}$ & $51 \%$ \\
\hline \multicolumn{2}{|l|}{ Interest in adapting to climate change } \\
\hline $\begin{array}{l}\text { I am interested in learning new skills outside of the } \\
\text { industry }\end{array}$ & $54 \%$ \\
\hline $\begin{array}{l}\text { I am interested in learning how I could better prepare } \\
\text { for drought }\end{array}$ & $83 \%$ \\
\hline $\begin{array}{l}\text { I attend workshops to get new ideas to better manage } \\
\text { drought }\end{array}$ & $60 \%$ \\
\hline $\begin{array}{l}\text { I talk about strategies to survive drought with other } \\
\text { graziers }\end{array}$ & $71 \%$ \\
\hline
\end{tabular}

Table 3. Proportion of graziers in the Burdekin region according to each "type" based on their mean adaptive capacity to climate variability $(n=100)$. Adaptive capacity is defined as comprising four essential dimensions. Individuals were typed according to $A / a, B / b, C / c, D / d$, where $A=$ high capacity to manage risk, $a=$ low capacity to manage risk, $B=$ high capacity to plan, learn and reorganize, $b=$ low capacity to plan, learn, and reorganize, $\mathrm{C}=$ high emotional and financial flexibility, $\mathrm{C}=$ low emotional and financial flexibility, $D=$ high level of interest in adapting to change, $\mathrm{d}=$ low level of interest in adapting to change. A grazier with particularly high adaptive capacity on all dimensions would be coded as ABCD, whereas a grazier with low adaptive capacity on all dimensions would be coded as abcd.

\begin{tabular}{|c|c|c|c|}
\hline abcd (12\%) & Abcd (4\%) & ABcd $(6 \%)$ & ABCd $(1 \%)$ \\
\hline$a b c D(4 \%)$ & $\mathrm{aBcD}(6 \%)$ & $\operatorname{abCD}(4 \%)$ & $\mathrm{ABcD}(7 \%)$ \\
\hline abCd (6\%) & $\mathrm{AbCd}(1 \%)$ & $A b c D(6 \%)$ & $\mathrm{AbCD}(10 \%)$ \\
\hline aBcd (3\%) & aBCd (5\%) & $\mathrm{aBCD}(7 \%)$ & ABCD (18\%) \\
\hline
\end{tabular}

risks such as drought, but these plans were developed on the basis of their own skills and knowledge. For example, only $21 \%$ of graziers "just hope for the best if there is a drought," and $90 \%$ of graziers thought that they were "good at doing what [they] do and trust [their] own decision." For the third dimension, graziers seemed to have more emotional flexibility than they did financial flexibility. For example, $98 \%$ of graziers suggested that their "financial situation is a constant source of worry," yet $83 \%$ of graziers said that "the good years help us to survive the bad years." For the fourth dimension, graziers were interested in adapting to climate change but were not interested in any of the strategies that we suggested. For example $83 \%$ of graziers were interested in how they "could better prepare for drought," while only $54 \%$ were prepared to "learn new skills outside of the industry," and only $60 \%$ were interested in attending "workshops to get new ideas to better manage drought.”

In Table 3 we present the types of graziers in the Burdekin region according to their adaptive capacity. Of the 16 possible combinations or five types of adaptive capacity (very low, low, moderate, high, and very high adaptive capacity), each combination was represented by at least one person in the Burdekin region (Table 3). The most common combination was a high rating on each of the four dimensions (ABCD). The second most common combination was a low rating on each of the four dimensions (abcd), suggesting that graziers in the Burdekin region were "extreme" in their capacities to adapt.

Twelve percent of graziers had very low capacity (Table 4), and around $18 \%$ of graziers had very high capacity. Nearly half of the sample $(43 \%)$ had high capacity to adapt to climate variability. Over half the sample $(53 \%)$ rated highly on the first dimension (risk), 53\% rated high on the second dimension (planning skills), $52 \%$ rated highly on the third dimension (security), and $62 \%$ rated highly on the fourth dimension (interest).

\section{DISCUSSION}

This research provides two new critical insights into graziers' adaptive capacity that might assist to sustain the grazing resource. First, there is significant heterogeneity in the adaptive 
Table 4. A summary of the proportion of graziers in the Burdekin region according to each "type" of adaptive capacity.

\begin{tabular}{lc}
\hline \multicolumn{1}{c}{ Level of adaptive capacity $^{1}$} & $\%$ of graziers in sample \\
\hline Very low capacity (abcd) & $12 \%$ \\
Low capacity (low on three dimensions) & $17 \%$ \\
Moderate capacity (low on two dimensions) & $28 \%$ \\
High capacity (low on one dimension) & $25 \%$ \\
Very high capacity (ABCD) & $18 \%$ \\
\hline
\end{tabular}

${ }^{1}$ Adaptive capacity is defined as comprising four essential dimensions. Individuals were typed according to $\mathrm{A} / \mathrm{a}, \mathrm{B} / \mathrm{b}, \mathrm{C} / \mathrm{c}, \mathrm{D} / \mathrm{d}$, where $\mathrm{A}=$ high capacity to manage risk, $\mathrm{a}=$ low capacity to manage risk, $B=$ high capacity to plan, learn and reorganize, $b=$ low capacity to plan, learn, and reorganize, $\mathrm{C}=$ high emotional and financial flexibility, $\mathrm{C}=$ low emotional and financial flexibility, $D=$ high level of interest in adapting to change, $d=$ low level of interest in adapting to change. A grazier with particularly high adaptive capacity on all dimensions would be coded as $A B C D$, whereas a grazier with low adaptive capacity on all dimensions would be coded as abcd.

capacity of graziers in the Burdekin region to climate variability. Many graziers exhibited very high levels of adaptive capacity whilst many displayed very low levels. In fact, of the 16 possible combinations describing adaptive capacity on rangelands, all combinations were represented to some extent. These results suggest that only some individuals will have the capacity to respond appropriately to policies and practices that enhance climate adaptation. Yet, by 2030, some areas of northern Australia will be experiencing more droughts and lower summer rainfall (Cobon et al. 2009). Although the impacts are likely to vary between ecological and geographic systems, climate change is expected to have noticeable detrimental effects on pasture growth, woody vegetation, production, gross margins, and biodiversity (Cobon et al. 2009). Our results suggest that the social heterogeneity in adaptive capacity that currently exists in the region will have profound influence on the sustainability of the social-ecological rangelands system.

Second, our results suggest that only about $18 \%$ of the sample rated highly on each of the dimensions of adaptive capacity. Although half of the graziers felt confident in their capacity to continue and prosper within their occupation, half did not, and although half of the graziers felt that they had the skills to manage and plan for climate events, half did not. Half of the graziers felt that they had emotional and financial security and the "headspace" to approach the future, and half did not. While $60 \%$ of the graziers were interested in developing new skills within or beyond the industry, $40 \%$ were not. The lesson here is that policies designed to enhance climate adaptation success that are rejected or ignored by graziers are likely to be interpreted, by those imposing them, as meeting "barriers" or "resistance." We think that a significant proportion of graziers need more information about how to manage for the uncertainty of climate variability and of climate change in particular (McNairn and Mitchell 1992). Many graziers need simple information about how to make the most of a good season, and how to reduce the biophysical impacts during a bad season. Many need to develop skills and strategies to deal with the range of probable scenarios for their region including how to prepare for extreme events. Many need financial advice about the costs of change, and they need encouragement to develop an interest in the future and be motivated to develop new skills to reduce the risks associated with climate variability. Well-designed policies should take into account the various dimensions of adaptive capacity and the associated limitations.

\section{MANAGEMENT IMPLICATIONS}

Any single initiative to address grazing land management practices is unlikely to address the needs of all graziers in the region (Campbell et al. 2006; Petheram et al. 2006). Rather, multiple management strategies that take into account the diversity in the adaptive capacity of resource users are more likely to be successful (Cros et al. 2004). Although this finding is not unique to this study (Campbell et al. 2006), our analysis has empirically shown that the reason that graziers need a range of initiatives with which to work is because many do not possess the capacity to respond to some strategies. If climate adaptation and the adoption of long-term strategies are to be successful, investing in the capacity of graziers to adapt is crucial (Newsham and Thomas 2011). Every effort should be made to move graziers from a "very low adaptive capacity" to a low or even moderate capacity (Vanclay 2004; Pannell et al. 2006). This might mean, for example, encouraging graziers to learn and plan with other graziers through facilitated networking opportunities (Measham 2009; Larson et al. 2010) or understanding what sorts of communication channels might be more suited to graziers who are not interested in workshops. By focusing on enhancing the four dimensions of adaptive capacity, we think that it is possible to bring closer the necessity of adapting to climate change and living sustainably within the rangelands.

\section{LITERATURE CITED}

Adger, W. N. 2000. Social and ecological resilience: are they related? Progress in Human Geography 24:347-364.

Adger, W. N., P. M. Kelly, A. Winkels, L. Q. Huy, and C. Locke. 2002. Migration, remittances, livelihood trajectories, and social resilience. AMBI0 31:358-366.

Andersen, E., B. Elbersen, F. Godeschalk, and D. Verhoog. 2007. Farm management indicators and farm typologies as a basis for assessments in a changing policy environment. Journal of Environmental Management 82:353-362.

ANDERSON, J. R. 2003. Risk in rural development: challenges for managers and policy makers. Agricultural Systems 75:161-167.

Ash, A., P. Mclntosh, B. Cullen, P. Carberry, and M. S. Smith. 2007. Constraints and opportunities in applying seasonal climate forecasts in agriculture. Australian Journal of Agricultural Research 58:952-965.

BAKER, J. T. 2002. Effects of climate change and variability on agricultural production systems. Agricultural Systems 82:94-96.

Berkes, F., and D. Jolly. 2001. Adapting to climate change: social-ecological resilience in a Canadian western Arctic community. Conservation Ecology 5(2):18. Available at: http://www.consecol.org/vol5/iss2/art18/.

Berry, H. L., A. Hogan, S. Peng Ng, and A. Parkinson. 2011. Farmer health and adaptive capacity in the face of climate change and variability. Part 1: health as a contributor to adaptive capacity and as an outcome from pressures coping with climate related adversities. International Journal of Environmental Research on Public Health 8:4039-4054.

Bohensky, E., S. Stone-Jovicich, S. Larson, and N. A. Marshall. 2010. Chapter two: adaptive capacity in theory and reality: implications for governance in the Great Barrier Reef region. In: D. Armitage and R. Plummer [EDs.]. Adaptive capacity and environmental governance. Heidelberg, Germany: Springer-Verlag. p. 23-43. 
Briske, D. D., N. F. Sayre, L. Huntsinger, M. Fernandez-Gimenez, B. Budd, and J. D. DERNER. 2011. Origin, persistence, and resolution of the rotational grazing debate: integrating human dimensions into rangeland research. Rangeland Ecology \& Management 64:325-334.

Briske, D. D., R. A. Washington-Allen, C. R. Johnson, J. A. Lockwood, D. R. Lockwood, T. K. Stringham, and H. H. Shugart. 2010. Catastrophic thresholds: a synthesis of concepts, perspectives, and applications. Ecology and Society 15(3):37. Available at: http://www.ecologyandsociety.org/vol15/iss3/art37/.

Brodie, J., C. Christie, M. Devlin, D. Haynes, S. Morris, M. Ramsay, J. Waterhouse, and H. YoRKSTON. 2001. Catchment management and the Great Barrier Reef. Water Science and Technology 43:203-211.

Brunson, M. W., AND L. Huntsinger. 2008. Ranching as a conservation strategy: can old ranchers save the new west? Rangeland Ecology \& Management 61:137147.

Burdge, R. J., and R. A. Robertson. 1990. Social impact assessment and the public involvement process. Environmental Impact Assessment Review 10:81-90.

Campbell, B. M., I. J. Gordon, M. K. Luckert, L. Petheram, and S. Vetter. 2006. In search of optimal stocking regimes in semi-arid grazing lands: one size does not fit all. Ecological Economics 60:75-85.

Cobon, D. H., G. S. Stone, J. O. Carter, J. Scanlan, N. R. Toombs, X. D. Zhang, J. WilLcocks, AND G. McKeon. 2009. The climate change risk management matrix for the grazing industry of northern Australia. Rangeland Journal 31:31-49.

Colding, J., T. ELmQVist, AND P. OLsson. 2004. Living with disturbance: building resilience in social-ecological systems. In: F. Berkes, J. Colding, and C. Folke [EDS.]. Navigating social-ecological systems: building resilience for complexity and change. Cambridge, UK: Cambridge University Press. p. 163-185.

Cros, M. J., M. Duru, F. Garcia, and R. Martin-Cloualire. 2004. Simulating management strategies: the rotational grazing example. Agricultural Systems 80:23-42.

Darnhofer, I., S. Bellon, B. Dedieu, and R. Milestad. 2010. Adaptiveness to enhance the sustainability of farming systems: a review. Agronomy for Sustainable Development 30:545-555.

Didier, E. A., AND M. W. Brunson. 2004. Adoption of range management innovations by Utah ranchers. Journal of Range Management 57:330-336.

EAKIN, H., AND J. Conley. 2002. Climate variability and the vulnerability of ranching in southeastern Arizona: a pilot study. Climate Research 213:271-281.

Fernandez-Gimenez, M. E., And C. N. Knapp. 2009. Understanding change: integrating rancher knowledge into state-and-transition models. Rangeland Ecology \& Management 62:510-521.

Folke, C., S. Carpenter, T. Elmovist, L. Gunderson, C. S. Holling, and B. Walker. 2002. Resilience and sustainable development: building adaptive capacity in a world of transformations. AMBIO 31:437-440.

Griener, R., O. Miller, and L. Patterson. 2008. The role of grazier motivations and risk attitudes in the adoption of grazing best management practices. Paper presented at the Annual Conference of the Australian Agricultural and Resource Economics Society; 5-8 February 2008; Canberra, ACT, Australia.

GundERSON, L. 1999. Resilience, flexibility and adaptive management-antidotes for spurious certitude? Ecology and Society 3(1):7. Available at: http://www. ecologyandsociety.org/vol3/iss1/art7/.

Gunderson, L., C. Folke, M. LeE, And C. S. Holling. 2002. In memory of mavericks. Conservation Ecology 6(2):19. Available at: http://www.consecol.org/vol6/iss2/ art19/.

GundeRSon, L., AND C. S. Holuing. 2002. Panarchy: understanding transformations in human and natural systems. Washington, DC, USA: Island Press. 505 p.

HerR, A., R. Greiner, and N. Stoeckl. 2005. Understanding adoption of on-farm conservation practices in the Burdekin dry tropics, Queensland. Australian Journal of Environmental Management 11:278-288.

Hobbs, N. T., K. A. Galvin, C. J. Stokes, J. M. Lackett, A. J. Ash, R. B. Boone, R. S. Reid, AND P. K. ThoRnton. 2008. Fragmentation of rangelands: implications for humans, animals, and landscapes. Global Environmental Change 18:776-785.

Howden, S. M., J. Soussana, F. N. Tubiello, N. Chhetri, M. Dunlop, and H. Meinke. 2007. Adapting agriculture to climate change. Proceedings of the National Academy of Sciences 104:19691-19696.

Hunt, L. P., S. Petty, R. Cowley, A. Fisher, A. J. Ash, and N. MacDonald. 2007. Factors affecting the management of cattle grazing distribution in northern Australia: preliminary observations on the effect of paddock size and water points. Rangeland Journal 29:169-179.
LaFlamme, M. 2011. A framework for sustainable rangeland livelihoods. Rangeland Journal 33:339-351.

Larson, S., T. G. Measham, and L. J. Willams. 2010. Remotely engaged? Towards a framework for monitoring the success of stakeholder engagement in remote regions. Journal of Environmental Planning and Management 53:827-845.

LI, X. L., Q. H. Yuan, L. Q. Wan, and F. He. 2008. Perspectives on livestock production systems in China. Rangeland Journal 30:211-220.

MarshalL, N. A. 2007. Can policy perception influence social resilience to policy change? Fisheries Research 86:216-227.

MaRSHALL, N. A. 2010. Understanding social resilience to climate variability in primary enterprises and industries. Global Environmental Change 20:36-43.

MarshaLL, N. A. 2011. Assessing resource dependency on the rangelands as a measure of climate sensitivity. Society and Natural Resources 24:1105-1115.

Marshall, N. A., D. M. Fenton, P. A. Marshall, and S. Sutton. 2007. How resourcedependency can influence social resilience within a primary resource industry. Rural Sociology 72:359-390.

Marshall, N. A., I. J. GoRdon, and A. J. Ash. 2011. The reluctance of resource-users to adopt seasonal climate forecasts that can enhance their resilience to climate variability. Climatic Change 107:511-529.

Marshall, N. A., and P. A. Marshall. 2007. Conceptualising and operationalising social resilience within commercial fisheries in northern Australia. Ecology and Society 12(11):11. Available at: http://www.ecologyandsociety.org/vol12/iss11/ art11/.

McAllister, R., N. Abel, C. Stokes, and I. Gordon. 2006a. Australian pastoralists in time and space: the evolution of a complex adaptive system. Ecology and Society 11(12):41. Available at: http://www.ecologyandsociety.org/vol11/iss12/art41/.

McAllister, R., I. Gordon, M. Janssen, And N. Abel. 2006b. Pastoralists' responses to variation of rangeland resources in time and space. Ecological Applications 16:572-583.

McAllister, R. R. J., I. J. Gordon, and M. A. Janssen. 2005. Trust and cooperation in natural resource management: the case of agistment in rangelands. In: A. Zerger and R. M. Argent [EDS.] Proceedings of Modsim 2005 International Congress on Modelling and Simulation; 12-15 December 2005; Melbourne, VIC, Australia. Canberra, ACT, Australia: Modelling and Simulation Society of Australia and New Zealand. p. 2334-2339.

McAluister, R. R. J., J. E. Gross, N. Abel, D. M. Stafford Smith, and Y. Maru. $2006 \mathrm{c}$. Australian rangelands as complex adaptive systems: a conceptual model and preliminary results. Environmental Modelling \& Software 21:1264-1272.

McKeon, G. M., W. B. Hall, B. K. Henry, G. S. Stone, and I. W. Watson. 2004. Pasture degradation and recovery in Australia's rangelands: learning from history. Brisbane, QLD, Australia: Queensland Department of Natural Resources, Mines and Energy. 1-255.

McNairn, H. E., AND B. MitcheLl. 1992. Locus of control and farmer orientationeffects on conservation adoption. Journal of Agricultural \& Environmental Ethics 5:87-101.

MeASHAm, T. G. 2009. Social learning through evaluation: a case study of overcoming constraints for management of dryland salinity. Environmental Management 43:1096-1107.

Measham, T. G., L. Brake, C. J. Robinson, S. Larson, C. Richards, and T. F. Smith. 2011 a. NRM engagement between remote dryland communities and government agencies: success factors from Australia. Journal of Arid Environments 75:968-973.

Measham, T. G., C. Richards, C. J. Robinson, S. Larson, and L. Brake. 2011b. Genuine community engagement in remote dryland regions: natural resource management in Lake Eyre Basin. Geographical Research 49:171-182.

Moon, K., AND C. CoCKLIN. 2011. A landholder-based approach to the design of privateland conservation programs. Conservation Biology 25:493-509.

Morrison, T. H., G. T. McDonald, AND M. B. LANE. 2004. Integrating natural resource management for better environmental outcomes. Australian Geographer 35:243258.

Nelson, B. S., And E. Robinson. 2009. Critical success factors of a whole of business extension approach for increased capacity of beef producers and improved enterprise profit and sustainability. Rangeland Journal 31:61-68.

Newsham, A. J., And D. S. G. Thomas. 2011. Knowing, farming and climate change adaptation in north-central Namibia. Global Environmental Change: Human and Policy Dimensions 21:761-770. 
Pannell, D. J., G. R. Marshall, N. Barr, A. Curtis, F. Vanclay, and R. Wilkinson. 2006. Understanding and promoting adoption of conservation practices by rural landholders. Australian Journal of Experimental Agriculture 46:1407-1424.

Petheram, L., B. M. Campbell, I. J. Gordon, M. K. Luckert, and S. Vetter. 2006. In search of optimal stocking regimes in semi-arid grazing lands: one size does not fit all. Ecological Economics 60:75-85.

Puigdefabregas, J., and T. Mendizabal. 1998. Perspectives on desertification: western Mediterranean. Journal of Arid Environments 39:209-224.

Sankey, T. T., J. B. Sankey, K. T. Weber, and C. Montagne. 2009. Geospatial assessment of grazing regime shifts and sociopolitical changes in a Mongolian rangeland. Rangeland Ecology \& Management 62:522-530.

Sietz, D., M. K. B. LUDEKE, AND C. WALTheR. 2011. Categorisation of typical vulnerability patterns in global drylands. Global Environmental Change: Human and Policy Dimensions 21:431-440.

Stafford Smith, D. M., G. M. McKeon, G. S. Stone, J. I. Syktus, J. O. Carter, N. R. Flood, D. G. Ahrens, D. N. Bruget, C. R. Chilcott, D. H. Cobon, R. A. Cowlwy, S. J. Crimp, G. W. Fraser, S. M. Howden, P. W. Johnston, J. G. Ryan, and D. A. Day. 2009 Climate change impacts on northern Australian rangeland livestock carrying capacity: a review of issues. Rangeland Journal 31:1-29.

Stafford Smith, D. M., G. M. McKeon, I. W. Watson, B. K. Henry, G. S. Stone, W. B. HALL, AND S. M. Howden. 2007. Learning from episodes of degradation and recovery in variable Australian rangelands. Proceedings of the National Academy of Sciences 104:20690-20695.

Stokes, C., R. R. J. McAllister, and A. Ash. 2006. Fragmentation of Australian rangelands: processes, benefits and risks of changing patterns of land use. Rangeland Journal 28:83-96.

Stokes, C. J., R. R. J. McAllister, A. J. Ash, And J. E. Gross. 2007. Changing patterns of land use and tenure in the Dalrymple Shire, Australia. In: K. A. Galvin, R. Reid,
R. H. Behnke, and N. T. Hobbs [EDS.]. Fragmentation in semi-arid and arid landscapes: consequences for human and natural landscapes. Canberra, ACT, Australia: CSIRO Publishing. p. 93-112.

Sutinen, J. G., and K. Kuperan. 1999. A socio-economic theory of regulatory compliance. International Journal of Social Economics 26:174-193.

THomAs, R. J. 2008. Opportunities to reduce the vulnerability of dryland farmers in central and west Asia and north Africa to climate change. Agriculture, Ecosystems \& Environment 126:36-45.

VancLAY, F. 2004. Social principles for agricultural extension to assist in the promotion of natural resource management. Australian Journal of Experimental Agriculture 44:213-222.

Walker, B., C. S. Holuing, S. Carpenter, and A. KinzIG. 2004. Resilience, adaptability and transformability in socio-ecological systems. Ecology and Society 9(2):5. Available at: http://www.ecologyandsociety.org/vol9/iss2/art5/.

WalkeR, B. H., AND M. A. Janssen. 2002. Rangelands, pastoralists and governments: interlinked systems of people and nature. Philosophical Transactions of the Royal Society of London Series B 357:719-725.

WALKER, S. 2005. Role of education and training in agricultural meteorology to reduce vulnerability to climate variability. Climatic Change 70:311-318.

Watson, I. W. 2004. I had the right number of sheep, but the wrong amount of rain. In: G. Bastin, D. Walsh, and S. Nicolson [EDS.]. Australian Rangeland Society 13th Biennial Conference; 5-8 July 2004; Alice Springs, NT, Australia. Canberra, ACT, Australia: Australian Rangeland Society. p. 291-292.

Willock, J., I. J. Deary, M. M. McGregor, A. Sutherland, G. Edwards-Jones, 0. Morgan, B. Dent, R. Grieve, G. Gibson, and E. Austin. 1999. Farmers' attitudes, objectives, behaviors, and personality traits: the Edinburgh study of decision making on farms. Journal of Vocational Behavior 54:5-36. 